\title{
Medium-term performance and maintenance of SUDS: a case- study of Hopwood Park Motorway Service Area, UK
}

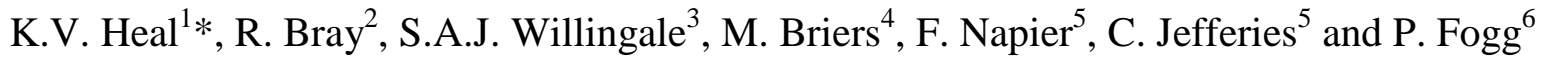 \\ ${ }^{1}$ The University of Edinburgh, School of GeoSciences, Crew Building, West Mains Road, Edinburgh EH9 3JN, \\ Scotland, UK \\ ${ }^{2}$ Robert Bray Associates Ltd., Fairfield, Coronation Road, Rodborough, Stroud, Gloucestershire GL5 3SB, \\ England, UK \\ ${ }^{3}$ Formerly University of Wales, Swansea, Wales, UK \\ ${ }^{4}$ Environment Agency, Phoenix House, Global Avenue, Leeds LS11 8PG, England, UK \\ ${ }^{5}$ University of Abertay Dundee, Bell Street, Dundee DD1 1HG, Scotland, UK \\ ${ }^{6}$ Cambridge Environmental Assessments, ADAS Gleadthorpe, Medan Vale, Mansfield, Nottinghamshire NG20 \\ $9 P F$, England, $U K$ \\ *Corresponding author, e-mail k.heal@ed.ac.uk
}

\begin{abstract}
One of the main barriers to implementing SUDS is concern about performance and maintenance costs since there are few well-documented case-studies. This paper summarizes studies conducted between 2000 and 2008 of the performance and maintenance of four SUDS management trains constructed in 1999 at the Hopwood Park Motorway Service Area, central England. Assessments were made of the wildlife value and sedimentation in the SUDS ponds, the hydraulic performance of the coach park management train, water quality in all management trains, and soil/sediment composition in the grass filter strip, interceptor and ponds. Maintenance procedures and costs were also reviewed. Results demonstrate the benefits of a management train approach over individual SUDS units for flow attenuation, water treatment, spillage containment and maintenance. Peak flows, pond sediment depth and contaminant concentrations in sediment and water decreased through the coach park management train. Of the current annual landscape budget of $£ 15,000$ for the whole site, the maintenance costs for SUDS only accounted for $£ 2,500$ compared to $£ 4,000$ for conventional drainage structures. Furthermore, since sediment was attenuated in the management trains, the cost of sediment removal after the recommended period of three years was only $£ 500$ and, in future, less frequent removal will be required.
\end{abstract}

\section{KEYWORDS}

Maintenance; management train; motorway service area; performance; sediment; SUDS

\section{INTRODUCTION}

SUDS are increasingly a standard component of water management in new developments in many countries, but the literature contains few reports of integrated studies of their longerterm performance, including flow attenuation, water and sediment quality, ecology, management and maintenance. Although the number of studies of SUDS increased when they were initially introduced within a country/region (e.g. the UK from the mid-1990s to the mid2000s), once SUDS became more widely accepted there was less incentive to examine their longer-term performance. Integrated studies of older SUDS are important for optimizing SUDS design, management and performance and for addressing some of the barriers to SUDS 
implementation, such as maintenance costs, particularly associated with sediment removal and disposal (McKissock et al., 2003). Measurements of the accumulation and composition of in situ sediment in SUDS ponds indicate typical sedimentation rates of $\sim 2 \mathrm{~cm}_{\text {year }}{ }^{-1}$ (Heal et al., 2006). However sedimentation rates may vary considerably and are dependent on pond design and its location within a management train. Guidance on the timing of sediment removal is limited although Bray and HR Wallingford (2004) recommend that sediment removal should be conducted approximately every three years. This paper presents data on the medium-term performance, management and maintenance costs for the SUDS at the Hopwood Park Motorway Service Area (MSA), UK. In particular it focuses on sediment accumulation and composition within different designs of SUDS management trains.

\section{METHODS}

\section{Site description}

Hopwood Park MSA $\left(56^{\circ} 22^{\prime} \mathrm{N}, 1^{\circ} 57^{\prime} \mathrm{W}\right)$ is located near Bromsgrove, Worcestershire, central England. It comprises an amenity building with car parking, coach parking, a centrally located fuel filling area and a separate HGV park. The MSA has a total area of 9 ha which drains into the local watercourse, the Hopwood Stream, and adjacent Wildlife Reserve. The concept of the management train was used to design a variety of SUDS in series to improve the flow and quality of runoff in stages prior to release into the local watercourse and to deal with unforeseen spillage events. The SUDS were designed with multiple objectives to: attenuate the 1 in 25 year storm runoff; provide a greenfield runoff rate of $51 \mathrm{~s} \mathrm{~s}^{-1} \mathrm{ha}^{-1}$; and treat the first $10 \mathrm{~mm}$ of storm runoff. The design was undertaken by Robert Bray Associates/ Baxter Glayster Consulting Ltd. before the publication of the CIRIA design manuals in the UK and followed guidance from the Environment Agency and a review of stormwater management manuals from the USA. Four management trains were completed in 1999 that receive runoff from: 1) the HGV park; 2) the coach park, fuel filling area, service yard and main access road; 3 ) the car park; and 4) the amenity building roof water (Figure 1).

The former two areas pose a serious pollution risk and have extended management trains. Runoff from the HGV park receives treatment in a 10-m wide grass filter strip, followed by a stone-filled and lined infiltration trench, a spillage basin (Pond 1) and a final attenuation wetland (Pond 2), with a further grass filter strip and swale for overflow in excess of the first flush. Although the system was designed with a high kerb so that spillages would be routed through the grass filter strip, in November 2000 a spillage of 2001 of diesel in the HGV park was hosed by the fire brigade directly into Pond 1 (C. Angel, pers. comm.), bypassing the upstream part of the management train. A gravel filter drain immediately adjacent to the HGV park was designed to trap sediment during construction and to protect the grass filter strip. A different approach was taken to managing drainage from the main access road, fuel filling area and coach park in that runoff is collected via a conventional gully and pipe system and passes through a proprietary silt and oil interceptor prior to discharge to a wetland/pond/wet swale management train (Ponds 3-6). The first basin (Pond 3) has an outlet valve to isolate any spillage event, and a subsidiary basin (Pond 5) receives runoff from the service yard. The car park and amenity building roof water were considered less likely to cause pollution and therefore have shorter treatment systems although the management train concept is applied to provide insurance against unforeseen spillage events. Car park runoff is collected via slotted kerbs into sub-surface, gravel-filled collector trenches that drain to a balancing pond (Pond 7). The amenity building roof water is piped to a balancing pond (Pond 8), with marginal wetland planting and fountain, before draining towards the Hopwood Stream. 
All ponds have artificial membrane liners covered with $30 \mathrm{~cm}$ subsoil. Management and maintenance of the aboveground SUDS comprises litter-picking and cutting of grass and wetland vegetation and has been conducted by contractors to Welcome Break, and advised by Robert Bray Associates. Contractors visit every two weeks as part of the overall landscape management of the MSA. The conventional drainage components (gullies and pipes) and the proprietary silt and oil interceptor are maintained by separate contractors. The interceptor was not maintained for the first 18 months and became blocked but it is now maintained by a specialist contractor every six months, as specified by the manufacturer. In line with the recommendation in Bray and HR Wallingford (2004) that sediment removal should be conducted every three years, in autumn 2003 (actually four years after construction), sediment was removed from Ponds 1-7 in a half-day operation costing $£ 500$ (2003 prices).

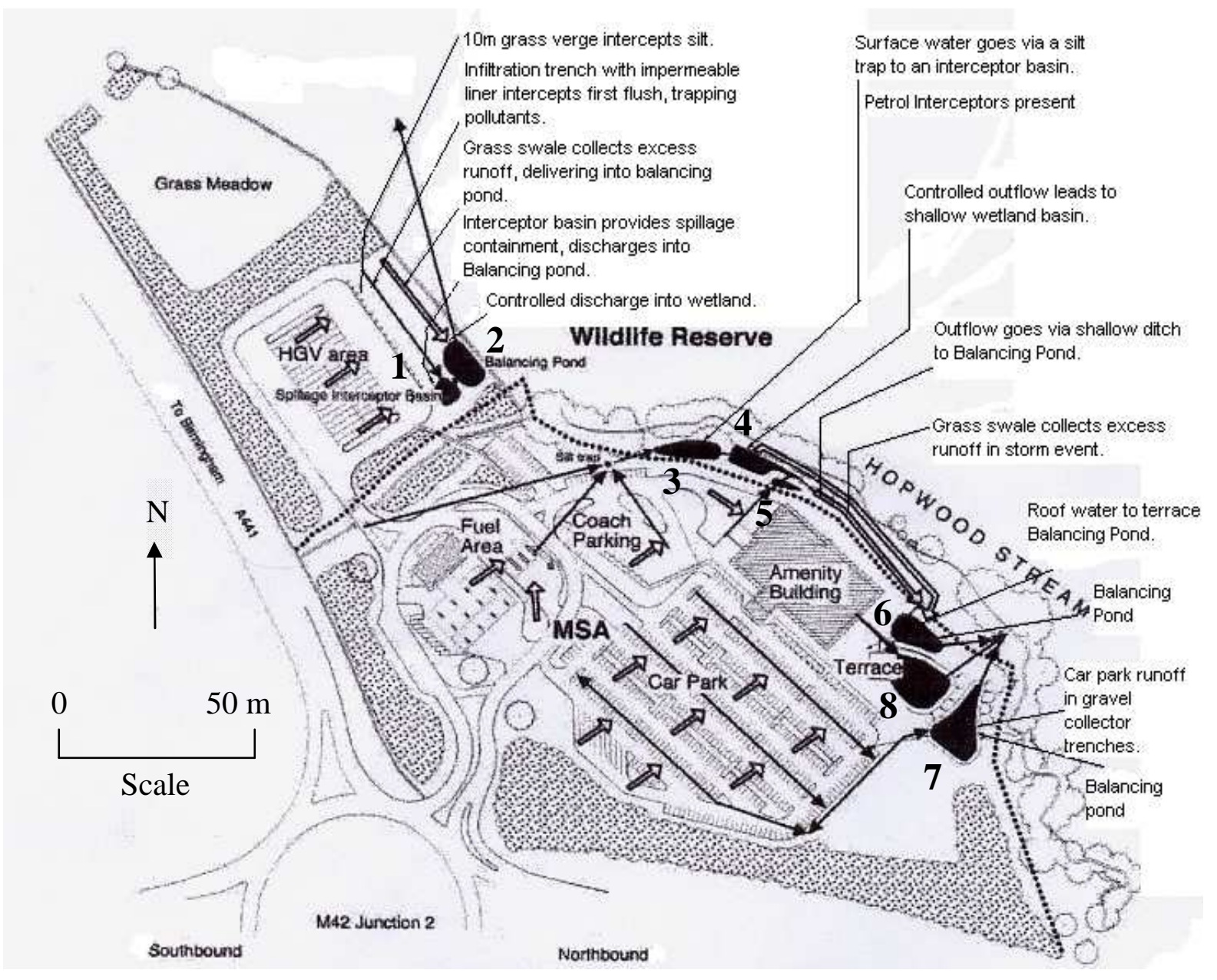

Figure 1. Layout of Hopwood Park Motorway Service Station Site and SUDS management trains. Numbers indicate ponds referred to in the text.

\section{SUDS assessment}

Several studies have been conducted by various organizations between 2000 and 2008 to assess the costs and performance of the SUDS at Hopwood MSA. The aims, timing and methodology employed by these studies are summarized in Table 1 . The results of many of these studies have been reported individually elsewhere (references given in Table 1) but this paper is the first to integrate them, together with new information on maintenance procedures and costs, to provide an overall assessment of the SUDS at Hopwood MSA and to draw conclusions that are relevant to the design and management of SUDS in general. 
Table 1. Summary of studies conducted of SUDS at Hopwood MSA between 2000 and 2007.

\begin{tabular}{|c|c|c|c|c|}
\hline Assessment & $\begin{array}{l}\text { Organisation } \\
\text { /Reference }\end{array}$ & Dates & Methods & Parameters assessed \\
\hline $\begin{array}{l}\text { Water } \\
\text { treatment } \\
\text { performance }\end{array}$ & $\begin{array}{c}\text { Environment } \\
\text { Agency }\end{array}$ & $\begin{array}{l}\text { May } \\
\text { 2000-Dec } \\
2005\end{array}$ & $\begin{array}{l}\text { Water sampled in } \\
\text { trains } 1-3 \text { on } 2-25 \\
\text { occasions (where } \\
\text { flowing) close to } \\
\text { rainfall events }\end{array}$ & $\begin{array}{c}\text { Water samples analyzed } \\
\text { for potentially toxic metals, } \\
\text { pH, nutrients, TSS, DOC. } \\
\text { A few samples analyzed } \\
\text { for hydrocarbons/oils }\end{array}$ \\
\hline $\begin{array}{l}\text { Biological } \\
\text { quality and } \\
\text { conservation } \\
\text { value }\end{array}$ & $\begin{array}{c}\text { Environment } \\
\text { Agency }\end{array}$ & $\begin{array}{l}2000- \\
2001\end{array}$ & $\begin{array}{c}\text { Macroinvertebrates } \\
\text { sampled in Ponds } \\
1-8 \text { and in } \\
\text { Hopwood Stream }\end{array}$ & $\begin{array}{l}\text { Identification to species } \\
\text { level where possible. } \\
\text { Calculation of BMWP } \\
\text { score, ASPT, various } \\
\text { indices, species rarity } \\
\end{array}$ \\
\hline $\begin{array}{l}\text { Aquatic } \\
\text { plants and } \\
\text { invertebrates, } \\
\text { biological } \\
\text { quality and } \\
\text { conservation } \\
\text { value }\end{array}$ & $\begin{array}{c}\text { Ponds } \\
\text { Conservation } \\
\text { Trust and } \\
\text { Environment } \\
\text { Agency } \\
\text { (2001), } \\
\text { Ponds } \\
\text { Conservation } \\
\text { Trust (2003) } \\
\end{array}$ & $\begin{array}{l}\text { Two } \\
\text { occasions } \\
\text { in Aug } \\
\text { and Oct } \\
2000\end{array}$ & $\begin{array}{c}\text { Plant and } \\
\text { invertebrate surveys } \\
\text { in Ponds } 1-8 \text { using } \\
\text { the National Pond } \\
\text { Survey } \\
\text { methodology }\end{array}$ & $\begin{array}{c}\text { Plant and } \\
\text { macroinvertebrate species } \\
\text { lists and estimates of } \\
\text { abundance. Assessment of } \\
\text { conservation value and } \\
\text { degree of impairment of } \\
\text { ponds using PSYM } \\
\text { analysis }\end{array}$ \\
\hline $\begin{array}{l}\text { Hydraulic } \\
\text { and water } \\
\text { treatment } \\
\text { performance }\end{array}$ & $\begin{array}{l}\text { Woods } \\
\text { Ballard et al. } \\
\quad(2005)\end{array}$ & $\begin{array}{c}\text { May } \\
\text { 2002- } \\
\text { June 2004 }\end{array}$ & $\begin{array}{l}\text { Monitoring of site } \\
\text { rainfall and flows in } \\
\text { train } 2 . \text { Water } \\
\text { sampled on } 13 \\
\text { occasions in train } 2 \\
\text { to complement EA } \\
\text { program. }\end{array}$ & $\begin{array}{c}\text { Water samples analyzed } \\
\text { for nutrients, TSS, Cu, Zn, } \\
\text { Pb, Ni, TPH }\end{array}$ \\
\hline $\begin{array}{l}\text { Sediment } \\
\text { depth and } \\
\text { composition } \\
\text { in Ponds } 1-7\end{array}$ & $\begin{array}{l}\text { Willingale } \\
\text { and } \\
\text { Environment } \\
\text { Agency. } \\
\text { Willingale } \\
\text { (2004) }\end{array}$ & $\begin{array}{c}\text { Sep-Dec } \\
2003\end{array}$ & $\begin{array}{l}\text { Sediment depth } \\
\text { measured prior to } \\
\text { removal. Sampling } \\
\text { and analysis of } \\
\text { sediment in situ and } \\
\text { on } 5 \text { occasions after } \\
\text { removal. }\end{array}$ & $\begin{array}{l}\text { Sediment analyzed for } \\
\text { potentially toxic metals, } \\
\text { PAHs, phenols, pH, } \\
\text { sulphate, leachable } \\
\text { ammonia, DOC, COD }\end{array}$ \\
\hline $\begin{array}{l}\text { Interceptor at } \\
\text { inlet to Pond } \\
3\end{array}$ & $\begin{array}{l}\text { Faram et al. } \\
\quad(2007)\end{array}$ & $\begin{array}{l}\text { Sep } 2005 \\
\text { and May } \\
2006\end{array}$ & $\begin{array}{l}\text { Sediment sampled } \\
\text { and depth measured } \\
\text { in interceptor } \\
\text { chamber }\end{array}$ & $\begin{array}{l}\text { Sediment analyzed for } \\
\text { particle size, potentially } \\
\text { toxic metals, PAHs, TPH }\end{array}$ \\
\hline $\begin{array}{l}\text { Sediment } \\
\text { quality in } \\
\text { HGV park } \\
\text { management } \\
\text { train }\end{array}$ & $\begin{array}{l}\text { Jefferies et } \\
\text { al. }(2008)\end{array}$ & $\begin{array}{c}\text { Jan, May } \\
2007\end{array}$ & $\begin{array}{l}\text { Sampling and } \\
\text { analysis of soil in } \\
\text { filter strip and } \\
\text { sediment from } \\
\text { Ponds } 1 \text { and } 2 \\
\end{array}$ & $\begin{array}{l}\text { Soil/sediment analyzed for } \\
\text { potentially toxic metals, } \\
\text { PAHs, TPH, pH, nutrients, } \\
\text { organic C }\end{array}$ \\
\hline $\begin{array}{l}\text { Management } \\
\text { and } \\
\text { maintenance } \\
\text { survey }\end{array}$ & $\begin{array}{c}\text { Robert Bray } \\
\text { Associates }\end{array}$ & $\begin{array}{l}\text { Jul } 2007 \\
\text { and Mar } \\
2008\end{array}$ & $\begin{array}{c}\text { Structured } \\
\text { interviews with } \\
\text { MSA Manager and } \\
\text { Operations staff } \\
\end{array}$ & $\begin{array}{l}\text { Benefits and disadvantages } \\
\text { of SUDS; management and } \\
\text { customer perspective; } \\
\text { maintenance costs }\end{array}$ \\
\hline
\end{tabular}




\section{RESULTS AND DISCUSSION}

\section{Flow attenuation}

Flow attenuation has only been studied in management train 2 (receiving runoff from the coach park, fuelling area and main access road) by Ballard Woods et al. (2005). They reported significant overall reductions and progressive attenuation of peak flows through this management train. The 2-year greenfield flow was exceeded by $70 \%$ of peak flows at the outfall of the conventional drainage network (outlet from interceptor), 30\% of peak flows downstream of Ponds 3 and 4 and by only $5 \%$ of peak flows at the inlet to Pond 6 (equivalent to 2 to 3 exceedances per year). Since further flow attenuation would be provided downstream in Pond 6 and prior to discharge to the Hopwood Stream the management train is expected to meet its design objective of achieving greenfield runoff conditions.

\section{Water treatment}

Results are summarized in Table 2 of the water quality survey conducted along three of the management trains during or shortly after rainfall events. The most contaminated runoff was from the HGV area, although runoff from the coach park and car park management trains was not sampled until after pre-treatment. Runoff from the car park was relatively uncontaminated after passage through gravel-filled collector trenches. The high ammonia concentrations measured in the HGV management train have been attributed to lorry drivers urinating near their vehicles (Ponds Conservation Trust, 2003). They may also result from the diesel spillage in November 2000 since the highest concentrations of ammonia, BOD and chloride were measured in Pond 1 inlet and outlet in January 2001, the nearest sample date after the spillage occurred. The relatively high standard deviations compared to mean values indicate variability in contaminant concentrations which is probably related to the sporadic and variable washoff of contaminants during rainfall events. Notwithstanding the diesel spillage in Pond 1, the mean concentrations of all contaminants measured, apart from ammonia, chloride and DOC (data not shown), were lower at the outlet of Pond 1 than at the interceptor outlet. Whilst the composition of runoff entering the interceptor is unknown, it is unlikely to be more contaminated than runoff from the HGV park. Although the interceptor was maintained for the first 18 months, these results suggest that treatment of runoff in the grass filter strip (which has required no maintenance apart from grass cutting) is highly effective.

Table 2. Mean ( \pm 1 standard deviation) of selected chemical parameters measured in water samples collected along management trains by the Environment Agency, 2000-2005. The number of samples at each point was 12-25.

\begin{tabular}{lcccccc}
\hline Sample Point & Ammonia & BOD & Chloride & TSS & Total Cu & Total Zn \\
\cline { 2 - 7 } & $\mathrm{mg} \mathrm{l}^{-1}$ & $\mathrm{mg} \mathrm{l}^{-1}$ & $\mathrm{mg} \mathrm{l}^{-1}$ & $\mathrm{mg} \mathrm{l}^{-1}$ & $\mu \mathrm{g} \mathrm{l}^{-1}$ & $\mu \mathrm{g} \mathrm{l}^{-1}$ \\
\hline HGV park management train & & & & & \\
HGV park runoff & $30.8(38.6)$ & $81.4(95.7)$ & $570(982)$ & $429(477)$ & $343(367)$ & $2,438(3,486)$ \\
Pond 1 inlet & $7.38(5.86)$ & $7.46(7.48)$ & $213(228)$ & $22.5(21.0)$ & $22(10)$ & $358(855)$ \\
Pond 1 outlet & $4.94(3.29)$ & $4.78(4.28)$ & $178(182)$ & $13.1(17.3)$ & $15(7)$ & $78(43)$ \\
\hline Coach park, fuelling area, main access road management train & & \\
Interceptor outlet & $0.37(0.49)$ & $11.4(9.94)$ & $166(261)$ & $78.5(91.0)$ & $45(43)$ & $230(200)$ \\
Pond 3 outlet & $0.76(0.89)$ & $12.2(10.3)$ & $154(252)$ & $30.1(29.8)$ & $27(25)$ & $167(99)$ \\
Pond 4 outlet & $0.55(0.44)$ & $7.39(5.17)$ & $114(104)$ & $22.2(14.6)$ & $15(11)$ & $100(55)$ \\
Pond 6 outlet & $0.20(0.21)$ & $3.50(5.50)$ & $69(58)$ & $8.04(4.94)$ & $5(3)$ & $27(19)$ \\
\hline Car park management train & & & & & \\
Car park runoff & $0.15(0.22)$ & $2.19(1.77)$ & $80(92)$ & $11.1(10.5)$ & $11(8)$ & $18(31)$ \\
Pond 7 outlet & $0.08(0.11)$ & $1.91(0.91)$ & $44(31)$ & $16.8(19.3)$ & $11(8)$ & $32(37)$ \\
\hline
\end{tabular}


In general water quality improved during passage through the more extended HGV park and coach park management trains, emphasizing the importance of implementing SUDS units in management trains rather than in isolation. Removal percentages calculated from concentration data were consistently high (70-90\%) for potentially toxic metals. Removal of ammonia, BOD and DOC in the HGV park management train was variable with medians of $80-90 \%$, although sometimes negative values occurred. However, removal percentages can give a misleading picture of SUDS water treatment performance where data are limited and/or the system influents are relatively clean (as in the car park runoff management train at Hopwood). A better approach for characterizing water treatment performance from the data available is comparison of effluent quality with appropriate environmental standards to evaluate the impact of the SUDS discharge on receiving waters and also the ecological potential of SUDS ponds/wetlands (Ponds Conservation Trust, 2003; Ballard Woods et al., 2005). The water chemistry results from all samples collected by the Environment Agency were compared with the mean contaminant concentrations measured in minimally impaired ponds in England and Wales (Ballard Woods et al., 2005). The percentage of water samples at each stage in the management trains that did not exceed these concentrations was calculated and the results for selected parameters are shown in Figure 2. The majority of water samples in the car park management train did not exceed the concentrations since drainage is relatively clean after passage through gravel-filled collector trenches. In the coach park management train ammonia, TSS and total Zn concentrations had decreased by Pond 6 to close to the mean concentrations in minimally impaired ponds, but only $68 \%$ of water samples did not exceed $2.5 \mathrm{mg} \mathrm{BOD} \mathrm{l}^{-1}$ at the end of this management train. In the HGV park management train, although the percentage of water samples that did not exceed mean concentrations in minimally impaired ponds increased through the management train, the elevated ammonia and BOD concentrations at the end of the management train might still impair the wildlife value of these SUDS (see ecology results and discussion later).

$\square \mathrm{NH} 4-\mathrm{N}<0.3 \mathrm{mg} / \mathrm{l} \square \mathrm{BOD}<2.5 \mathrm{mg} / \mathrm{l} \square \mathrm{TSS}<19 \mathrm{mg} / \mathrm{l} \otimes \mathrm{tot} \mathrm{Zn}<0.097 \mathrm{mg} / \mathrm{l}$

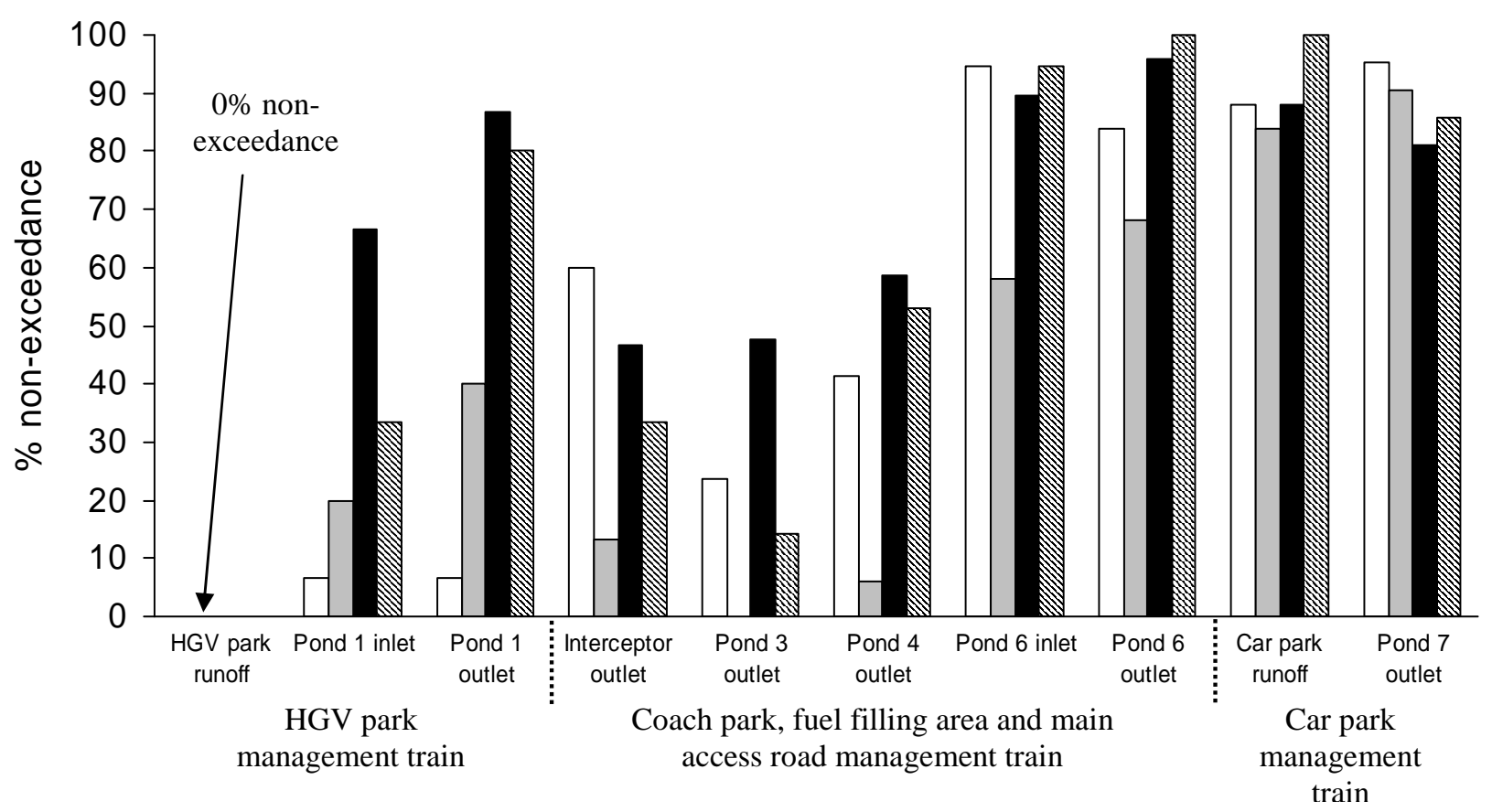

Figure 2. Percentage of water samples collected by Environment Agency 2000-05 that did not exceed mean contaminant concentrations of selected parameters measured in minimally impaired ponds in England and Wales. 


\section{Sediment accumulation}

No substantial sediment accumulation has been observed in the management trains at Hopwood, apart from the gravel filter trench designed for construction runoff and the interceptor and Pond 3 (discussed below). The grass filter strip in the HGV park management train has not received any maintenance, apart from grass cutting, but there is evidence of only limited sediment accumulation. In their 2007 survey of sediment composition in the HGV park management train, Jefferies et al. (2008) were able to sample up to $20 \mathrm{~cm}$ depth of material from an area of apparent preferential flow in the first 1-3 m of the filter strip, but across the rest of the strip the maximum depth from which samples could be obtained was 10 $\mathrm{cm}$, suggesting efficient trapping of sediment. They also found no sediment in the collector trench downstream of the filter strip, although the possibility cannot be ruled out that flow may bypass the trench. In the coach park management train sediment is being captured by the interceptor. Inspections estimated that the volume of material in the unit increased from $3 \mathrm{~m}^{3}$ in September 2005 to $4 \mathrm{~m}^{3}$ in May 2006. An increase in sediment $\mathrm{D}_{50}$ values (median diameter) from $30 \mu \mathrm{m}$ in 2005 to $112 \mu \mathrm{m}$ in 2006 was attributed to the presence of sand used on MSA surfaces for absorbing fuel spillages and/or deicing (Faram et al., 2007).

Sediment depth and composition in Ponds 1-7 were assessed in September-December 2003 by Willingale (2004) in conjunction with the first routine sediment removal from the ponds, recommended every three years in Bray and HR Wallingford (2004). The maximum sediment depth $(30 \mathrm{~cm})$ was measured near the outlet from Pond 3. Depths decreased along the management trains. Sediment depths were $\sim 12 \mathrm{~cm}$ in Ponds 4 and 5 but only $0-3 \mathrm{~cm}$ in Ponds 6 and 7. Pond 1 had depths $<10 \mathrm{~cm}$, whilst the sediment depth in Pond 2 was too small to measure. Very little organic sediment was observed in the ponds, probably due to oxidation in well-oxygenated waters in the shallow basins. The mean sedimentation rate across all ponds is $1.7 \mathrm{~cm}$ year $^{-1}$, within the range of values reported from other urban ponds $\left(0.2-3.2 \mathrm{~cm}\right.$ year ${ }^{-1}$, Heal et al., 2006). Prior to the sediment depth survey it had been anticipated that an excavator would be required for a whole day to remove sediment from the ponds but, because little sediment was found, the machine was only required for half a day. To minimize the impact on ecology, sediment was removed in October 2003 by pulling out $25 \%$ of pond vegetation and attached sediment. The material was spread at the edge of the basins to dewater for two months and then the vegetation matter was taken away for composting on site. It had been intended to incorporate any sediment residue into the raised banks surrounding the ponds but, because the amount of material remaining was negligible, this action was not required.

\section{Sediment composition}

In the HGV park management train, contaminant concentrations in the grass filter strip generally decreased with distance from the tarmac and with depth, although the highest TPH concentration occurred at $3 \mathrm{~m}$ distance in an area of obvious preferential flow (Jefferies et al., 2008; Table 3). The highest contaminant concentrations occurred in Pond 1, presumably due to the diesel spillage in 2000, despite the removal of $25 \%$ sediment in 2003. Although the spillage affected sediment quality in Pond 1, this is preferable to direct discharge into the Hopwood Stream. In the coach park management train the highest sediment contaminant concentrations were in the interceptor and in Pond 3 immediately downstream and concentrations progressively decreased along the train (Table 3). Contaminant concentrations in Pond 3 sediment were similar to those in the interceptor and higher than all measurements in the HGV management train. This implies that grass filter strips are highly effective in runoff pre-treatment compared to conventional drainage measures, probably because conditions in the filter strip are more favorable for microbial degradation of organic contaminants. Since metal contaminants cannot be broken down it is possible that metal 
accumulation within the management train will eventually impact on biological functioning. In such instances Jefferies et al. (2008) suggest that only the top $10 \mathrm{~cm}$ of soil would require replacement and the small volume of soil removed could easily be redistributed on site.

Table 3. Contaminant concentrations in sediment in the HGV park and coach park management trains compared with sediment standards. All concentrations are in $\mathrm{mg} \mathrm{kg}^{-1} \mathrm{dry}$ weight. Concentrations in excess of the standards (where they exist) are shown in bold.

\begin{tabular}{|c|c|c|c|c|c|c|}
\hline & $\mathrm{Cd}$ & $\mathrm{Cu}$ & $\mathrm{Pb}$ & $\mathrm{Zn}$ & $\mathrm{TPH}$ & Total PAHs \\
\hline \multicolumn{7}{|c|}{ HGV park management train } \\
\hline 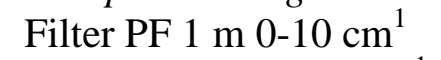 & 0.4 & 71 & 66 & 351 & 398 & 5.16 \\
\hline 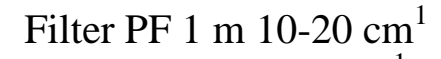 & 0.3 & 51 & 69 & 146 & 153 & 1.72 \\
\hline Filter PF $3 \mathrm{~m}_{0}-10 \mathrm{~cm}^{1}$ & 0.3 & 50 & 52 & 199 & 1,199 & 16.2 \\
\hline 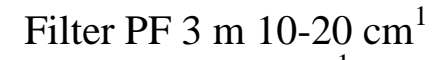 & 0.2 & 30 & 39 & 106 & 86 & 1.56 \\
\hline Filter $3 \mathrm{~m} \mathrm{0}-10 \mathrm{~cm}^{1}$ & 0.3 & 28 & 40 & 145 & 277 & 10.0 \\
\hline Filter $6 \mathrm{~m} 0-10 \mathrm{~cm}^{1}$ & 0.3 & 24 & 36 & 118 & 151 & 2.61 \\
\hline Filter $9 \mathrm{~m} 0-10 \mathrm{~cm}^{1}$ & 0.3 & 26 & 40 & 123 & 166 & 3.55 \\
\hline Pond $1^{1}$ & 0.7 & 192 & 92 & 733 & 3,152 & 19.2 \\
\hline Pond $2^{1}$ & 0.6 & 89 & 67 & 393 & 629 & 4.27 \\
\hline \multicolumn{7}{|c|}{ Coach park, fuelling area, main access road management train } \\
\hline Interceptor ${ }^{2}$ & 2.16 & 350 & 193 & 2,500 & 10,660 & 112 \\
\hline Interceptor $^{2}$ & 1.15 & 224 & 101 & 1,790 & 26,030 & 64.7 \\
\hline Pond $3^{3}$ & 1.78 & 352 & 183 & 2,580 & --- & 108 \\
\hline Pond $4^{3}$ & 0.586 & 215 & 136 & 1,290 & --- & --- \\
\hline Pond $5^{3}$ & 1.03 & 161 & 120 & 1,680 & --- & 30.1 \\
\hline Pond $6^{3}$ & 0.115 & 23.9 & 32.1 & 75.5 & --- & 4.29 \\
\hline Standards ${ }^{4}$ & 10 & 110 & 250 & 820 & 1,500 & --- \\
\hline
\end{tabular}

${ }^{1}$ Sampled in 2007 by Jefferies et al. (2008). Soil from the grass filter strip was sampled at 1, 3, 6 and $9 \mathrm{~m}$ from the pavement edge and at a depth of $0-10 \mathrm{~cm}$. In an area of apparent preferential flow (PF) samples were taken from two different depths $\left(0-10 \mathrm{~cm}\right.$ and 10-20 cm). ${ }^{2}$ Samples collected in 2005 and 2006 (Faram et al., 2007). ${ }^{3}$ Sampled in 2003 by Willingale (2004). TPH not measured. Insufficient sample from Pond 4 for PAH analysis. ${ }^{4}$ Values below which severe ecological effects are not thought to occur (Ontario Ministry of Environment, 1993).

\section{Ecology and wildlife value}

Conclusions about the medium-term ecological quality and functioning of the Hopwood SUDS ponds cannot be drawn because surveys by the Environment Agency and Ponds Conservation Trust were conducted only one to two years after construction when the ponds were still colonising with species. The main results from these surveys, fully documented in Ponds Conservation Trust and Environment Agency (2001) and Ponds Conservation Trust (2003), are reported here. The total number of naturally colonizing wetland plant species recorded across all ponds in autumn 2000 was 21 . The numbers ranged between four in Pond 5 , impacted by service yard runoff, to 12 in Pond 6, at the lower end of the coach park management train (Ponds Conservation Trust and Environment Agency, 2001). In addition to planted species at least two other wetland species are likely to have been brought in by accident probably as seeds in the soil of purchased plants and grass mix. The number of macroinvertebrate species recorded in 2000 surveys varied between 22 and 58 in individual ponds, with a mean for all eight ponds of 36.9, slightly greater than the mean value for minimally impaired ponds in England and Wales (Ponds Conservation Trust, 2003). A PSYM (Predictive System for Multimetrics) analysis (methodology described in Environment Agency and Ponds Conservation Trust, 2002) was conducted on the summer 2000 plant and macroinvertebrate data to assess the extent to which the ponds are fulfilling their ecological 
potential. The ponds had PSYM scores between $33 \%$ and $61 \%$, with the highest scores of 50$61 \%$ occurring in Ponds 4, 6 and 8 at the latter stages of management trains. Scores below $50 \%$ indicate ponds that are likely to be significantly below their full ecological potential. These scores are unsurprising as the analysis was conducted only one year after pond construction when colonization is still likely to be ongoing. Ponds Conservation Trust (2003) recommended that clean water will be required if minimally impaired ponds are desired within SUDS schemes. At Hopwood the ponds with the highest number of plant and invertebrate species occurred towards the end of the management trains where water and sediment contamination is lowest. Repeat ecological surveys are required in order to determine the longer-term wildlife value of the SUDS ponds at Hopwood and also to assess whether initially rapid colonization has been sustained or has levelled off as observed in other newly-created ponds in England and Wales (Williams et al., 2008).

\section{Perception, Management and Maintenance}

Structured interviews with the Site and Services Operational Managers at Hopwood MSA were conducted in 2007 and 2008 to obtain information on the perception, management and maintenance of the SUDS. Information and awareness about the SUDS appeared not to be widely and systematically disseminated amongst those concerned: "Most information regarding the system was...picked up along the way". The SUDS were well-regarded by users of the MSA: "People often say... it's hard to believe...that we're actually on the side of a motorway because you sit out here... surrounded by countryside and...a nice pond". Furthermore there were no perceived disadvantages of the SUDS, apart from people throwing chairs into ponds. No flooding had occurred, even after the exceptionally heavy rainfall in central England in summer 2007, and the health and safety officer does not have any concerns about the SUDS. The maintenance of the aboveground SUDS was regarded as unproblematic, routine and cost-effective compared to conventional drainage systems: "it's such a small amount of money...it's just like weeding an extra bed ...it's as easy and simple as that...if that wasn't there, something else would be which would need to be maintained anyway". The routine maintenance of the aboveground SUDS is conducted as part of the landscape management of the whole MSA at a total annual cost of $£ 15,000$. Of this SUDS only account for $£ 2,500$, compared to $£ 4,000$ for maintaining conventional drainage structures (interceptor, gullies and pipes). No long-term maintenance or performance problems are envisaged with the SUDS: "as long as it's well maintained I don't foresee any long term problems". The only additional SUDS maintenance that has been conducted since construction in 1999 was sediment removal in Ponds 1-7 in October 2003 at a total cost of $£ 500$ (2003 prices) for inspection, vegetation and sediment removal, and transfer of dewatered vegetation matter for composting on site. Since only limited amounts of sediment were found in the ponds because most is retained in the management train, particularly in the filter strip below the HGV park, it is anticipated that sediment removal will not need to be conducted so frequently in the future (perhaps every 10 years). However, alteration of the drainage system in the HGV park when it was extended in 2007 so that most runoff now enters Pond 1 directly by a new gully system, bypassing the filter strip and trench, means that the functioning, maintenance and costeffectiveness of this management train are likely to be severely compromised in the future.

\section{CONCLUSIONS}

The Hopwood Park MSA case-study demonstrates the benefits of the management train in attenuating and treating flow, silt and associated contaminants at a number of stages. This also means that the maintenance of SUDS is less costly and time-consuming and more straightforward than conventional drainage measures. 
The key findings from the case-study for practitioners are:

- Where possible, design SUDS so that sediment is trapped in areas from which it can be easily removed, e.g. filter strips. This avoids expensive and habitat-disruptive maintenance to ponds and wetlands and also reliance on belowground conventional drainage that can be costly to maintain. In situ remediation of organic contaminants and nutrients also occurs more rapidly in filter strips than in submerged sediments.

- To maximise the ecological value of SUDS, high pollutant and sediment loads should not be discharged directly to ponds/wetlands without pre-treatment.

- A need to educate designers, contractors, managers and maintenance staff about SUDS as ill-informed actions can adversely impact on the performance and maintenance costs of SUDS.

\section{ACKNOWLEDGEMENT}

The authors thank the Welcome Break staff at Hopwood for their support. Caroline Aistrop transcribed the interview tapes. Work conducted at Hopwood MSA by Jefferies et al. (2008) was funded by SNIFFER. The following kindly provided access to reports and data: Penny Williams (Pond Conservation), Bridget Woods Ballard (HR Wallingford) and Mike Faram (Hydro International plc). The authors acknowledge the contributions of Environment Agency staff: Gary Tarling, Richard Silver and Graham Folkes-Skinner for assistance to Sophie Willingale; Phil Green for macroinvertebrate survey results; Phil Chatfield for his comments; Richard Silver and colleagues for collection and analysis of water samples.

\section{REFERENCES}

Bray, R. and HR Wallingford (2004). The Operation and Maintenance of Sustainable Drainage Infrastructure, Report SR 626, HR Wallingford, Wallingford, UK.

Environment Agency and Ponds Conservation Trust (2002). A Guide to Monitoring the Ecological Quality of Ponds and Canals using PSYM, Ponds Conservation Trust: Policy \& Research, Oxford Brookes University, Oxford, UK.

Faram, M.G., Iwugo, K.O. and Andoh, R.Y.G. (2007). A field study of sediments captured by flow-through stormwater interceptors. In: Proc. Novatech 2007, 6th Int. Conf. on Sustainable Techniques and Strategies in Urban Water Management, Lyon, France, 25-28 June 2007, pp.641-648.

Heal, K.V., Hepburn, D.A. and Lunn, R.J. (2006). Sediment management in sustainable urban drainage (SUD) ponds. Wat. Sci. Tech., 53(10), 219-227.

Jefferies, C., Napier, F., Fogg, P. and Nicholson, F. (2008). Source Control Pollution in Sustainable Drainage. Final Report, Project UEUW01, SNIFFER, Edinburgh, Scotland.

McKissock G., D’Arcy B.J., Wild T.C., Usman F. and Wright P.W. (2003). An evaluation of SUDS guidance in Scotland. In: Bruen, M. (ed.): Diffuse Pollution and Basin Management. Proc. 7th Int. Specialised Conf. on Diffuse Pollution and Basin Management, Dublin, Ireland, 17-21 August 2003, pp. 4-11-4-17.

Ontario Ministry of Environment (1993). Guidelines for the Protection and Management of Aquatic Sediment Quality in Ontario. Ontario Ministry of the Environment.

Ponds Conservation Trust and Environment Agency (2001). Hopwood MSA Sustainable Urban Drainage Scheme: plant and aquatic macroinvertebrate survey 2000, Draft Report, Ponds Conservation Trust: Policy \& Research, Oxford Brookes University, Oxford, UK.

Ponds Conservation Trust (2003). Maximising the Ecological Benefits of SUDS Schemes, Report, Ponds Conservation Trust: Policy \& Research, Oxford Brookes University, Oxford, UK.

Willingale, S.A.J. (2004). A study into the bioremediation of silt from a sustainable drainage system. BSc Dissertation, Department of Geography, Swansea University, Wales, UK.

Williams, P., Whitfield, M. and Biggs, J. (2008). How can we make new ponds biodiverse? A case study monitored over 7 years. Hydrobiologia, 597, 137-148.

Woods Ballard, B., Dimova, G., Weisgerber, A., Kellagher, R., Abbot, C., Maneiro Franco, E., Smith, H. and Stovin, V. (2005). Benefits and Performance of Sustainable Urban Drainage Systems, Report SR 667, HR Wallingford, Wallingford, UK. 